Kalina Wojciechowska

\title{
Fragmenty polecające w listach apostoła Pawła
}

Na związek między epistolografią a retoryką i różnymi gatunkami literackimi zwracali uwagę już starożytni autorzy. Niejednokrotnie nie da się nawet przeprowadzić ścisłej granicy pomiędzy listem a traktatem, esejem ${ }^{1}$, czy mową, zwłaszcza że wśród zajęć w szkołach retorycznych odbywały się też ćwiczenia z epistolografii, a podręczniki pisania listów cieszyły się dużym powodzeniem - jak choćby jeden z najbardziej znanych podręczników epi-

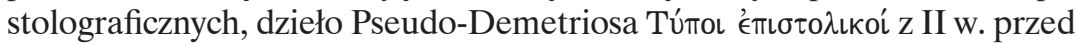
Chr. Uczniowie pisali listy na różne zadane tematy z uwzględnieniem zasad retoryki i ćwiczyli dostosowywanie formy oraz treści listu do osoby adresata (tzw. $\pi \rho \gamma \gamma \nu \mu \nu \alpha ́ \sigma \mu \alpha \tau \alpha$ ), dlatego listy często mają kompozycję typową dla mów. Jako wzorce wykorzystywano najchętniej pisma wybitnych osobistości o wielkiej wartości literackiej. Nic więc dziwnego, że wiele listów pochodzących z II w. przed Chr. aż do II, a nawet IV w. po Chr. zawiera nie tylko podobny układ, części, ale wręcz sformułowania. Zjawisko to można zaobserwować również w tzw. listach lub choćby formułach polecających czyli epistolae

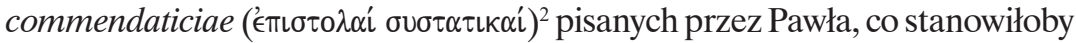
kolejny dowód wpływu retoryki antycznej na twórczość apostoła.

Nie ma co prawda wypowiedzi apostoła Pawła na temat jego stosunku do kultury antycznej, prawdopodobnie jednak był on jednym z lepiej wykształconych chrześcijan ${ }^{3}$ I w. i oprócz spuścizny hebrajskiej cenił sobie także kul-

${ }^{1}$ L. MaŁunowiczówna, Z zagadnień epistolografii starochrześcijańskiej, „Roczniki Humanistyczne" KUL, t. 25, 1977, s. 68.

${ }^{2}$ R. AndrzeJewski, Struktura antycznego listu polecającego, „Roczniki Humanistyczne” KUL, t. 21, 1973, s. 17.

${ }^{3}$ Paweł pochodził z Tarsu w Cylicji, miasta, które było centrum edukacyjnym zwłaszcza w dziedzinie retoryki i filozofii, i mogło konkurować nawet z Atenami i Aleksandrią, o czym zaświadcza Strabon w Geografica hypomnemata, 14, 3, 5. Naukę pobierał też w Jerozolimie u Gamaliela, co nie wyklucza retorycznego wykształcenia, bowiem w Jerozolimie wpływy grecko-rzymskie były w tym czasie bardzo wielkie, a egzegeza żydowska w dużym stopniu korzystała ze zdobyczy hellenistycznej tradycji retorycznej. 
turę zarówno Greków jak i Rzymian. Świadczy o tym choćby posługiwanie się w listach rzymskim imieniem głównym Paulus (w formie zhellenizowanej - „Paulos”), a nie np. imieniem hebrajskim „Saul”4, przytoczenie słów greckiego poety Menandra w 1 Kor $15,33^{5}$, prawdopodobnie cytowanie poety i filozofa Epimenidesa w Tt 1, 12, znajomość greckiej gramatyki, retoryki ${ }^{6}$ i dialektyki, należących do tzw. nauk trywialnych, a więc podstawowych i elementarnych ${ }^{7}$. Tak wynika zwłaszcza z mowy apostoła wygłoszonej na Areopagu, przytoczonej przez Łukasza w Dz 17, 22-31, z przestrzegania przed zgubnymi skutkami filozofii, najprawdopodobniej gnostyckiej, w Kol 2,8 , czy wreszcie, a może przede wszystkim, ze stosowania w listach pewnego rodzaju kompilacji elementów charakterystycznych dla poetyki hebrajskiej i klasycznych figur retorycznych, takich jak osadzone w poetyce semickiej paralelizmy antytetyczne podobne do klasycznych antytez ${ }^{8} 1$ Kor 1,17 , również związane z paralelizmem anafory 1 Kor 1, 26, charakterystyczny dla dialektyki pewien rodzaj wnioskowania dedukcyjnego, sylogizmu entymematy 1 Kor 2, 10-11. Być może nawet można zaryzykować tezę, iż zaadaptował „Dobrą Nowinę z Palestyny na język religijny ówczesnego świata", a ówczesny świat posługiwał się pojęciami i formami zaczerpniętymi z kultury hellenistycznej. Podobne próby syntezy myśli judaistycznej i filozofii greckiej podejmowali Arystobul z Paneas, anonimowy autor Listu do Filokratesa, zwany Pseudo-Arysteaszem ${ }^{10}$, czy o wiele skuteczniej Filon z Aleksandrii, a nieco później biskup Rzymu Klemens (Żyd z pochodzenia, zaznajomiony z literaturą i filozofią grecką, zwłaszcza stoicką).

Poza tym na podstawie analogii z innymi wczesnymi pismami wykształconych chrześcijan (choć żadne nie jest tak wczesne jak listy Pawła) można

${ }^{4}$ Por. J. Gnilka, Pawet z Tarsu, Kraków 2001, s. 30-31.

${ }^{5}$ Tamże, s. 40. Autor zwraca jednak uwagę, że akurat ten cytat mógł funkcjonować jako obiegowe powiedzenie.

${ }^{6} \mathrm{Na}$ temat znajomości retoryki klasycznej przez Pawła zdania są jednak podzielone. Niektórzy sądzą, że występowanie elementów retorycznych w mowach i listach apostoła nie świadczy o jego wykształceniu, lecz jedynie o inteligencji i wykorzystaniu doświadczeń zdobytych w czasie podróży; por. M. Tracz, Z badań nad retoryką w listach św. Pawła, „Collectanea Theologica", 2001, z. 1, s. 105.

${ }^{7}$ Trywialny oznacza tu przynależność do tzw. trivium, trzech dyscyplin - gramatyki, retoryki i dialektyki - stanowiących podstawę wykształcenia. Z kolei arytmetyka, muzyka, geometria i astronomia tworzyły quadrivium.

${ }^{8}$ Nie ma racji M. TKacz, art. cyt., s. 105, która uważa, że Paweł stosuje antytezy. Podobieństwo, nie mówiąc już o tożsamości klasycznych antytez i właściwych poetyce semickiej paralelizmów antytetycznych jest pozorne; por. J. ZIOMEK, Retoryka opisowa, Wrocław-Warszawa-Kraków 1990, s. 40.

${ }^{9}$ H. Chadwick, Myśl wczesnochrześcijańska a tradycja klasyczna, Poznań 2000, s. 12.

${ }^{10}$ Por. J. Zieliński, Jerozolima, Ateny, Aleksandria, Wrocław 2000, s. 87nn. 
wysnuć dalsze wnioski, co do stosunku apostoła i innych przedstawicieli chrześcijaństwa pierwszych wieków do kultury antycznej. A stosunek ten był na ogół pozytywny ${ }^{11}$, jak wynika z pism Justyna Męczennika ${ }^{12}$, Atenagorasa $^{13}$, czy później Orygenesa i Klemensa Aleksandryjskiego.

Pierwotne chrześcijaństwo, które samo nie wypracowało sobie jeszcze własnych form ${ }^{14}$, chętnie korzystało ze zdobyczy zwłaszcza retoryki antycznej, ze szkoły Izokratesa, udoskonalonej i zaadaptowanej na grunt rzymski przez Cycerona, oraz z tzw. wymowy azjańskiej - Asiatica dicto

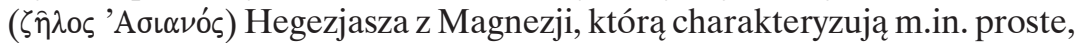
krótkie, ale bardzo dźwięczne zdania ${ }^{15}$. Nie należy więc też jakoś sztucznie rozgraniczać pomiędzy retoryką i epistolografią rzymską i grecką, ponieważ w świecie antycznym idee literackie były rozprzestrzeniane po całym imperium romanum.

Nic zatem dziwnego, że apostoł Paweł, jako wykształcony Żyd i zarazem obywatel rzymski, przyswoił sobie antyczne zasady retoryki i epistolografii, przede wszystkim Cycerona i Kwintyliana, a więc także normy pisania listów polecających. Charakterystyczne dla epistolae commendaticiae elementy znajdują się w każdym w zasadzie z pism apostoła. Szczególnie jednak widoczne są w Liście do Filipian, w którym Paweł rekomenduje swoich współpracowników - Tymoteusza i Epafrodyta, oraz Liście do Filemona, w którym apostoł wstawia się za zbiegłym niewolnikiem Onezymem u jego pana (4-22). Ten ostatni list sprawia wręcz wrażenie wzorca epistolografii wstawienniczej, czy rekomendacyjnej ${ }^{16}$.

${ }^{11}$ Choć nie można pominąć też całkowitego potępienia szeroko pojętej kultury klasycznej np. u Tacjana, który uważał retorykę pogańską za stworzoną jedynie w celu ,niesprawiedliwości i oszczerstwa" (TATIAnus, Oratio adversus Graecos, 1, PG 6, 805), czy Tertuliana, który mimo swej wielkiej niechęci do literatury klasycznej, korzystał z racji swojego doskonałego wykształcenia ze zdobyczy sztuki retorycznej (por. A. Eckmann, Pisarze chrześcijańscy wobec kultury klasycznej, „Roczniki Humanistyczne” KUL, t. 47, 1999, s. 94; H. CHADWICK, dz. cyt., s. 12).

${ }^{12}$ Zob. Justinus, Apologia II, 13, PG, 6, 465-468, przekład M. Michalski, Antologia literatury patrystycznej, t. 1, z. 1, Warszawa 1969, s. 154-155.

${ }^{13}$ Por. A. Eckmann, art. cyt., s. 90-91.

${ }^{14}$ Za pierwszą retorykę chrześcijańską uważa się dopiero IV księgę De doctrina christiana Augustyna; por. K. BuRKE, Tradycyjne zasady retoryki, w: O retoryce, wyb. J. Z. LichańsKI, Warszawa 1995, s. 30. Z IV w. pochodzi też chrześcijańska przeróbka wzorców z podręcznika epistolograficznego Pseudo-Proklosa wymieniająca różne typy listów z ich charakterystyką.

${ }^{15}$ J. Niemirska-Pliszczyska, Paralelizm stylistyczny w listach Pawła z Tarsu jako kontynuacja retoryki antycznej, „Roczniki Humanistyczne” KUL, t. 20, z. 3, 1972, s. 31.

${ }^{16} \mathrm{Na}$ silny związek Listu do Filemona z retoryką zwrócili uwagę m.in. F. F. CHURCH, Rhetorical Structure and Design in Paul's Letter to Philemon, Harv. TheolRev 7, 1978; J. Gnilka, Der Philomenbrief (Herders Theologischer Kommentar t. 10, z. 4), Freiburg 1982. 
Celem zarówno listów, jak i mów polecających - epistolografia bowiem, jak wspomniano, pozostawała pod przemożnym wpływem retoryki $\mathrm{i}^{17} \mathrm{i}$ ulegała jej wpływom - było wywołanie życzliwości dla osoby i przedstawianej kwestii ${ }^{18}$. Zazwyczaj w mowach i listach polecających wyróżnia się:

- wstęp - exordium,

- przedstawienie sprawy - causae propositio,

- zakończenie - epilogus.

\section{Exordium}

Starożytni rozróżniali dwa rodzaje wstępów: greckie mpooínıov czyli principium stosowane przy sprawach jasnych, niewymagających zbyt wielu zabiegów, polegające tylko na przedstawieniu osoby polecanej, oraz $€ \phi o \delta \varsigma$ czyli insinuatio, rozbudowane wprowadzenie, którego wymagały sprawy bardziej skomplikowane ${ }^{19}$. U Pawła spotyka się zarówno pierwszy rodzaj wstępu, który jest właściwie tylko biletem polecającym wymieniającym już na początku imię osoby rekomendowanej np. Rz 16, 1 - „Polecam wam Febę naszą siostrę, która jest diakonisą Kościoła w Kenchrach”; (także 1 Kor 16, 10-11; Ef 6, 21-22; Kol 4, 7-9; Flp 2, 19. 29; Tt 3, 12-13, jak i drugą rozbudowaną formę wprowadzającą Flm 4-10) ${ }^{20}$ : „Dziękuję mojemu Bogu zawsze, gdy wspominam ciebie w moich modlitwach, ponieważ słyszę o twojej miłości i wierze, którą masz względem Pana Jezusa i wobec wszystkich świętych. Oby twój udział w wierze doskonalił się przez poznawanie każdego dobra, które jest w nas i prowadzi do Chrystusa. Doznaje bowiem wielkiej radości i zachęty z powodu twojej miłości, gdyż przez ciebie, bracie, zostały pokrzepione serca świętych. Chociaż więc w Chrystusie mam prawo nakazywać ci, co należy czynić, to w imię miłości raczej proszę, ja, stary Paweł, teraz też i więzień Jezusa Chrystusa, za moim dzieckiem, które zrodziłem w więzach, za Onezymem". Ten drugi rodzaj wstępu, zgodnie z zasadami retoryki antycznej, dzieli się na dwie części: pierwsza przygotowuje adresata tzw. captatio benevolentiae, np. artificium benevolentiae colligendae, jak u Cycerona czy później u Grzego-

${ }^{17}$ Po odrzuceniu początkowych i końcowych fragmentów większości listów Pawła, pozostałe teksty można by zakwalifikować do któregoś z rodzajów retoryki antycznej - sądowego, np. 2 Kor, doradczego (u Arystotelesa - retoryka debatująca) - np. 1 Kor, czy okolicznościowego (u Arystotelesa - retoryka ostentacyjna, epideiktyczna, „popisowa”), np. 1 Tes; por. M. TKACZ, art. cyt., s. 106; K. BuRKe, dz. cyt., s. 54.

${ }^{18}$ R. ANDRZEJEWSKI, art. cyt., s. 18.

${ }^{19}$ Por. Kwintylian, Inst. IV 1, 42.

${ }^{20}$ P. Stuhlmacher, Der Brief an Philemon (EKK 18), Neukirchen-Vluyn 1975, s. 31 proponuje nieco krótszy wstęp: 4-7. 
rza z Nazjanzu' ${ }^{21}$, gdzie wspomina się o więzach przyjaźni, o spotkaniach, korespondencji, wspólnych przeżyciach, studiach, nauce itp., a dopiero w drugiej następuje przedstawienie osoby polecanej. Podobnie postępuje Paweł w najkrótszym ze swoich listów. Już w pierwszych słowach wstępu usiłuje zdobyć przychylność Filemona, kiedy wspomina mu o dziękczynnych modlitwach. Odwołuje się do miłości i wiary Filemona wobec Jezusa i wierzących w Niego, wspomina o radości jakiej doznaje z powodu działalności Filemona wśród chrześcijan, prawdopodobnie w Kolosach, a jednocześnie podkreśla jednak swoje prawo do nakłaniania Filemona do podjęcia jakiegoś postępowania. Tak jednak nie czyni właśnie w imię wspomnianej i podkreślanej miłości. Na captatio benevolentiae w wierszu 5 zwrócili uwagę już starożytni chrześcijańscy komentatorzy, m.in. Jan Chryzostom i Jan Damasceński ${ }^{22}$, którym nieobce były przecież zasady retoryki antycznej! Znamienne jest zdanie Jana Chryzostoma w II homilii na List do Filemona: „Nie zaraz z początku prosi o łaskę, lecz skoro najpierw wyraził podziw dla męża, pochwalił go za dobre uczynki, dał niemały dowód swej miłości wobec niego [...] i skoro powiedział, że wielu znajdzie wspomożenie u niego, a on na wszystkich uważa i słucha ich, - wtedy na końcu umieszcza i łaskę, najbardziej go tym zawstydzając. Jeśli bowiem inni uzyskują spełnienie swych próśb, to tym bardziej Paweł"23.

Czasem można, jak Grzegorz z Nazjanzu, rozbudować insinuatio poprzez rozwijanie jakiegoś cytatu, dostosowanego do sprawy. U Pawła co prawda bezpośrednie cytaty np. z Septuaginty nie występują, niemniej apostoł posługuje się pewną stylizacją Biblii greckiej. Np. w Flm 4 świadomie zapewne używa frazy „mój Bóg” charakterystycznej dla psałterza greckiego (np. Ps 3,$8 ; 5,3 ; 7,2.4 ; 21,2$ ), a w Flm 5 stosuje wyrażenie znane z apo-

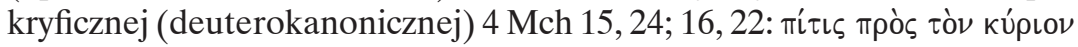
'I widać też w Flm 7, co oczywiście można potraktować jako swego rodzaju loci communes, stosowane w retoryce odwołania do wspólnego dziedzictwa, zrozumiałe zarówno dla nadawcy jak i dla adresata ${ }^{25}$.

${ }^{21}$ Szczególnie długie wprowadzenie zastosował też Kwintylian Inst. IV 1, 43.

${ }^{22}$ Zob. A. Jankowski, List do Filemona, w: A. JANKowski, Listy więzienne (Pismo Święte Nowego Testamentu, t. 8), s. 319.

${ }^{23}$ Jan ZŁotousty, Na List do Filemona - homilia II, w: św. JAN ZŁotousty, Homilie na listy pasterskie św. Pawła i na List do Filemona, przekład T. Sinko, Kraków 1947, s. 374.

${ }^{24}$ P. Stuhlmacher, dz. cyt., s. 32.

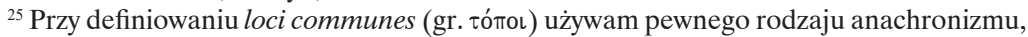
gdyż w retoryce antycznej oznaczały one powszechnie stosowane chwyty oratorskie, schematy argumentacji, ustalone przez długotrwałą tradycję ujęcia tematów, czy wreszcie wzorcowe sposoby wypełniania poszczególnych części przemówienia. W tym ujęciu cały list należałoby 
Po tej rozbudowanej pierwszej części wstępu, następuje druga, o wiele krótsza, zawierająca przedstawienie osoby polecanej. Niejednokrotnie wspomina się tu o jej koneksjach rodzinnych, pozycji społecznej, zawodowej, przyjaźni łączącej ją z różnymi osobistościami, które mogłyby robić wrażenie na adresacie itp. Bardzo wyraźnie widać to u Pawła, który zwykle poleca swoich współpracowników: Febę, diakonisę w Kenchrach, która otoczyła opieką samego Pawła (Rz 16, 1-2), Tymoteusza, który tak, jak Paweł, wykonuje dzieło Pana (1 Kor 16, 10), Tychika, umiłowanego brata, wiernego sługę i wraz z Pawłem niewolnika w Panu (Kol 4, 7), Onezyma, wiernego i umiłowanego brata (Kol 4, 9), Marka, kuzyna Barnaby, współpracownika dla Królestwa Bożego, który stał się dla Pawła pociechą (Kol 4, 10-11), Zenasa, znawcę Prawa (Tt 3, 13). Stosuje też bardziej rozbudowane opisy: „Poślę [...] Tymoteusza [...]. Nikogo przecież nie mam tak jak on myślącego, kto szczerze troszczyłby się o wasze sprawy [...]. Jak dziecko ojcu, tak on razem ze mną służył Ewangelii”" (Flp 2, 19. 20. 22); czy pochodząca z tego samego listu charakterystyka Epafrodyta: „[...] mojego brata, współpracownika i towarzysza w walce, którego wysłaliście, aby mi służył w potrzebie [...] wykonując służbę dla Pana był bliski śmierci” (Flp 2, 25. 30). Później Grzegorz z Nazjanzu, należący przecież do elity intelektualnej, pobierający wykształcenie m.in. w szkole retorów w Cezarei Kapadockiej i w pogańskiej szkole w Atenach, użyje frazeologii przypominającej krótkie formuły Pawłowe: „Fortunatus, który wręczy ci ten list, to mój przyjaciel i domownik; jeśli potrzeba dodatku - pochwały godny diakon” (List 85), czy krócej jeszcze: „wręczam ci przez ten list mego brata i współdiakona Georgiusza, męża wybranego przeze mnie, a Kościołowi bardzo użytecznego" (List 150) ${ }^{26}$.

Bardziej rozwinięte przedstawienie osoby polecanej zawiera List do Filemona, gdzie Onezym nazywany jest dzieckiem Pawła zrodzonym w więzieniu, który niegdyś był dla Filemona nieużyteczny, a teraz zarówno dla swego dawnego pana jak i dla Pawła stał się pożyteczny. Największe jednak wrażenie na odbiorcy powinien zrobić fakt, że Paweł nazywa Onezyma swoim sercem (w. 12)!

W pismach teoretycznych, zwłaszcza Kwintyliana, jednak ostrzega się, aby długość wstępu dostosowana była do sprawy: „Zatem długość wstępu dostosowana jest do sprawy. Sprawy proste mianowicie wymagają krótkiego; zawikłane, podejrzane i niesławne - dłuższego [...] Ale unika się przesad-

zaliczyć do topiki. We współczesnym ujęciu toposy oznaczają właśnie tradycyjne motywy, czy tematy świadczące o ciągłości kultury śródziemnomorskiej i jej źródłach w mitologii, religii, obrzędowości; por. M. GŁowiński, T. KostKiewiczowa, A. OKopień-SŁawińsKa, J. SŁawiński, Podręczny stownik terminów literackich, Warszawa 1994, s. 130.

${ }^{26}$ Tłumaczenie za J. STAHR, POK 15, Poznań 1933. 
nego jego rozciągania, aby nie wydawało się na początku, że [wstęp] jest wyodrębniony i aby nie zmęczyć tego, którego musi przygotować”27.

Opracowano nawet uniwersalny krótki wstęp exordium vulgare, który stosowano przedstawiając różne sprawy, zmieniając jedynie szczegóły i imiona osób polecanych. Być może Paweł korzystał z tego wzorca, gdyż wszystkie jego krótkie formuły polecające, jak można było wyżej zauważyć, są zbudowane wedle tych samych schematów: imię osoby polecanej i jej stosunek do Pawła. Przypomina to stosowaną w epistolografii antycznej, np. u Cycerona, praktykę zawierania wprowadzenia i rekomendacji w jednym zdaniu: „Chciałbym, żebyś tak potraktował A. Fufia, jednego z moich najbardziej zaufanych przyjaciół, najpilniejszego i najgorliwszego z nas, człowieka uczonego i najbardziej godnego przyjaźni całej ludzkości oraz twojej, jak mnie osobiście przyjmowałeś" (fam. XIII, 3$)^{28}$. Co ciekawe, bardzo podobnie zakończony fragment znajduje się w Liście do Filemona (w. 17): „Jeśli więc poczuwasz się do wspólnoty ze mną, przyjmij go tak, jak mnie”.

Wyjątkowe pod tym względem są List do Filipian i wspomniany właśnie List do Filemona, gdzie apostoł zdaje się ignorować zalecenia Kwintyliana dotyczące długości wstępu. Można oczywiście snuć przypuszczenia i hipotezy, dlaczego te fragmenty listów są tak bardzo rozbudowane i czy rzeczywiście jest to proporcjonalne do całej treści, a przede wszystkim, czy jest to uzasadnione? W Liście do Filipian tak rozbudowane wstępy części rekomendacyjnych (polecajacych Tymoteusza, a potem Epafrodyta) ${ }^{29}$ nie znajdują wyraźnego uzasadnienia. O ile jeszcze sprawa Epafrodyta może być postrzegana jako niejasna (Epafrodyt opuścił Pawła w trudnej chwili i tym naraził się Filipianom, jak sugeruje Flp 2, 25-30) ${ }^{30}$, to już rekomendacja Tymoteusza z powodzeniem mogłaby być zastąpiona biletem polecającym, jak w innych listach. Proporcje wydają się nieco zachwiane, zważywszy, że obie części wstępu i nierozerwalnie z nim związane zasadnicze przedstawienie prośby zajmują większą część fragmentu rekomendacyjnego Listu do Filipian! Podobnie rzecz wygląda w Liście do Filemona, gdzie wstęp stanowi ponad połowę tekstu. Gdyby kierować się wskazówkami Kwintyliana, można by sądzić, że sprawa Onezyma była bardzo zagmatwana, skomplikowana i niejasna. Z drugiej strony nie stanowi ona chyba precedensu, skoro po-

\footnotetext{
${ }^{27}$ Przekład własny.
}

${ }^{28}$ Przekład własny.

${ }^{29}$ Fragment Flp 2, 19-30 sprawia wrażenie odrębnego listu polecającego dla Tymoteusza i Epafrodyta; por. S. Mędala, Świadectwo Mocy Chrystusa (List do Filipian), w: Dzieje Apostolskie. Listy Św. Pawła (Wprowadzenie w myśl i wezwanie ksiag biblijnych, red. J. FrankowskI, t. 9), Warszawa 1997, s. 398.

${ }^{30}$ Tamże, s. 385. 
dobny list pod koniec I w. napisał również Pliniusz Młodszy do Sabiniana: „Wyzwoleniec twój, na którego, jak powiedziałeś - gniewasz się, przybył do mnie, rzucił mi się do stóp i tam pozostał leżąc. Wiele płakał, wiele prosił, wiele też milczał, w sumie uczynił mi akt prawdziwej skruchy. Naprawdę wierzę w jego poprawę. [...] Daruj mu przez wzgląd na jego młodość, daruj mu przez wzgląd na jego łzy, daruj mu przez wzgląd na Twoją wyrozumiałość" ${ }^{\prime}$. Kolejny list Pliniusza do Sabiniana wskazuje, że sprawa została zakończona pomyślne. Z IV w. pochodzi list wstawienniczy z Aleksandrii do Flaviosa Abinnaiosa, rzymskiego oficera kawalerii, chrześcijanina, za zbiegłym ze służby żołnierzem ${ }^{32}$; z V w. natomiast - list Izydora z Peluzjum do chrześcijańskiego prawnika imieniem Hero, właściciela zbiegłego niewolnika, w którym to Izydor prosi Herona o wybaczenie dla świadomego swojej winy uciekiniera, posiłkując się ewangelicznym komentarzem do Modlitwy Pańskiej z Mt 6, 15; oraz przykładami z Łk 7, 37nn; Mt 9, 9nn; J 4, 5nn i Mt 9, 2nn ilustrującymi upadek i przebaczenie ${ }^{33}$. Być może sprawę Onezyma komplikował dodatkowo fakt, że zbieg okazał się również złodziejem (jak sugeruje w. 18), albo nie okazał skruchy, bo o tym Paweł nie wspomina.

\section{Causae propositio}

Rekomendacja stanowi zasadniczą część zarówno listu, jak i mowy polecającej tzw. causae propositio. Zwykle zawiera charakterystykę osoby polecanej. Element ten może, jak już wspomniano, występować we wstępie lub na końcu listu. Teoretycy retoryki przestrzegają, że powinna być ona jasna, zwięzła $i . .$. prawdopodobna ${ }^{34}$, a więc chodzi o siłę argumentacji na poparcie osoby polecanej. Te same lub inne argumenty, jakie wystąpiły już we wstępie, mogą też pojawić się w zakończeniu. W przeciwieństwie do mów, w listach polecających causae propositio jest zazwyczaj, zgodnie z zaleceniami Kwintyliana, bardzo zwięzła i niejednokrotnie tak silnie związana ze wstępem, że trudno rozdzielić obie części ${ }^{35}$. U Pawła bywa różnie, choć na ogół lakoniczność rekomendacji i jej ścisły związek z zagajeniem odpowiadają sugestii Kwintyliana. Wyjątkami są znów List do Filipian i do Filemona z rozbudowanymi charakterystykami Epafrodyta: „[...] którego wysłaliście, aby mi służył w potrzebie, ponieważ tęsknił do was wszystkich i bardzo się smucił, gdy usłyszeliście, że zachorował. Zachoro-

\footnotetext{
${ }^{31}$ C. Plinius Caecilius Secundus, Epistolarum liber IX, 21. 24, przekład własny.

${ }^{32}$ P. Stuhlmacher, dz. cyt., s. 26.

${ }^{33}$ Tamże.

${ }^{34}$ R. ANDRZEJEWSKI, art. cyt., s. 21.

${ }^{35}$ Tamże.
} 
wał bowiem tak bardzo, że był bliski śmierci. Bóg jednak zlitował się nad nim. [...] Tym szybciej więc go posłałem, abyście na jego widok znów się ucieszyli. [...] Wykonując służbę dla Chrystusa był bliski śmierci. Naraził bowiem swoje życie, aby wypełnić brak waszej służby względem mnie” (Flp 2, 26-28. 30) i Onezyma: „On, kiedyś dla ciebie nieużyteczny, teraz zaś dla ciebie i dla mnie jest bardzo pożyteczny. Jego też, to jest moje serce, posyłam do ciebie z powrotem. Zamierzałem go zatrzymać przy sobie, żeby zamiast ciebie służył mi w więzach nałożonych z powodu ewangelii. Bez twojej decyzji jednak nie chciałem tego uczynić, abyś wyświadczył mi dobro nie pod przymusem lecz z własnej woli. Może też z tego powodu został oddalony od ciebie na pewien czas, abyś go odzyskał na zawsze, już nie jako niewolnika, ale więcej niż niewolnika - umiłowanego brata, szczególnie dla mnie, a jeszcze bardziej dla ciebie, i w ciele, i w Panu. Jeśli więc poczuwasz się do wspólnoty ze mną, przyjmij go tak, jak mnie. Jeśli zaś wyrządził ci jakąś niesprawiedliwość albo jest ci coś winien, zalicz to na mój rachunek" (Flm 11-18).

Forma rekomendacji może być rozmaita, np. Cyceron używa czasowni-

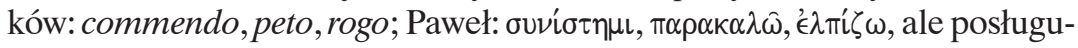
je się też imperativem i dłuższymi formami opisowymi (np. „Jeśli przybędzie [...], uważajcie, żeby przebywał wśród was nie obawiając się niczego; [...] wyposaż odpowiednio na drogę, aby niczego im nie brakowało"); Grzegorz

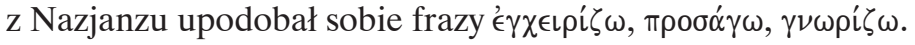

W argumentacji fragmentów polecających Paweł stosuje zazwyczaj tzw. ethos (odwołanie się do charakteru nadawcy i odbiorcy), podczas gdy logos (odwołanie się do racjonalnego rozumowania z wykorzystaniem np. sylogizmu lub paradygmatu czyli przykładu, wzorca, np. Abrahama), i pathos (odwołanie się do emocji odbiorców, bardzo rzadkie u Pawła, aby uniknąć posądzenia o manipulację) występują sporadycznie. Posługując się ethosem Paweł odwołuje się najczęściej do samego siebie, buduje tym swoją wiarygodność i podkreśla jednocześnie swoją wartość. Jak można było zauważyć - wszystkie rekomendowane osoby konfrontuje ze sobą. Nawet w Liście do Filemona, choć akcentuje charakter adresata, to jednak osoba nadawcy nie pozostaje w cieniu, a nawet pojawiają się autoprezentacyjne wzmianki, np. o uwięzieniu (w. 9), czy frazy sugerujące wielki autorytet i poważanie, jakim cieszy się Paweł u Filemona (w. 8; 17; 19-20; 21).

\section{Epilogus}

Ostatnią częścią mowy jest zakończenie - epilogus, na które składają się trzy elementy: enumeratio (kolejne wymienienie), amplificatio (rozwi- 
nięcie) oraz commiseratio (wyrażenie współczucia), w większości listów polecających są one jednak albo zupełnie pomijane, albo występują pojedynczo. W zakończeniach listów zauważyć można natomiast tendencję do pewnego rodzaju antycypacji - nadawca wyraża swą wdzięczność i przedstawia adresatowi korzyści, jakie płynąć będą w przyszłości z pozytywnego ustosunkowania się do osoby rekomendowanej. Zapewnia więc o przyjaźni, modlitwie, obfitych łaskach Bożych, a nawet o korzyściach, jakie odniesie adresat z samego tylko faktu otrzymania listu. Cyceron pisze: „moje listy będą miały dla ciebie największe znaczenie" ${ }^{36}$ (fam. III, 1); „To i mnie będzie bardzo miło a i tobie potem przyjemnie; poznajesz bowiem człowieka wielkiej uczciwości, łagodności i godnego poszanowania" ${ }^{37}$ (fam. XIII, 23), wyraża swoją wdzięczność: „Tę rzecz [...], jeśli mi uczynisz, moją o twojej względem mnie życzliwości nadzieję potwierdzisz, tym samym [...] najwdzięczniejszego, najbardziej zobowiązanego najlepszego męża, do twojej przyjaźni twoim całym dobrodziejstwem pozyskasz"38 (fam. XIII, 29). Paweł wyraża to w nieco inny sposób; używając form optativu i imperativu wspomina o radości i pokrzepieniu serca: „Tak, bracie, obym dzięki tobie doświadczył radości w Panu. Pokrzep moje serce w Chrystusie!” (Flm 20). Po czym daje jeszcze wyraz przekonaniu nie tylko o posłuszeństwie Filemona, ale wręcz o jego „nadgorliwości” w spełnieniu prośby: „Piszę do ciebie, gdyż jestem przekonany o twoim posłuszeństwie i wiem, że uczynisz więcej niż to, o czym mówię" (w. 21). W Liście do Filipian natomiast zakłada, że przyjmując Tymoteusza adresaci listu zyskają troskliwego i pełnoprawnego zastępcę Pawła, a przyjmując Epafrodyta - doznają radości (2, 20. 28).

Grzegorz z Nazjanzu z kolei wyraża w zakończeniach swych listów głęboką wdzięczność i zapewnia o pamięci w modlitwie: „Będziesz miał ode mnie nie tylko modlitwy, lecz także rozsławienie twojego urzędu wśród wszystkich, których znam" (List 146). Czasem jeszcze w zakończeniu prośba jest ponawiana, o czym była mowa wyżej.

Jak już wspomniano, apostoł posługuje się również tropami i figurami retorycznymi. Nawet w tak krótkich tekstach, jakimi są List do Filemona i fragment polecający w Liście do Filipian, znaleźć można tropy (metafory - np. Flm10 i 12, metonimie - np. Flm 7 i 20, hiperbole - Flm 16) i figury (apozjopezje - np. Flm 8-9, porównanie - np. Flp 2, 22).

\footnotetext{
${ }^{36}$ Przekład własny.

${ }^{37}$ Przekład własny.

${ }^{38}$ Przekład własny.
} 
Widać więc, że listy i mowy polecające funkcjonowały w dwu formach: rozbudowanej i krótkie, mającej niejednokrotnie postać tzw. „, biletu polecającego" 39 . Obie postaci są znane i stosowane przez apostoła Pawła. Dłuższa wersja charakteryzuje się przede wszystkim rozbudowanym wstępem, ale jest też wyraźnie staranniej zredagowana. Nieprzypadkowo podano tu trzy przykłady związków epistolografii z retoryką - Cycerona, jako przedstawiciela kultury łacińskiej, Grzegorza z Nazjanzu, jako przedstawiciela kultury greckiej i apostoła Pawła, któremu nieobce były obie szkoły retoryczne, choć więcej cech wspólnych ma ze zwięzłym językiem Cycerona niż rozbudowanymi frazami charakterystycznymi dla Wschodu. Można też za R. Andrzejewskim zaryzykować twierdzenie o „trwałości tradycji doctrinae epistolandi i jej jednorodności zarówno na gruncie greckim, jak i łacińskim"40. Apostoł Paweł dodał tylko treści chrześcijańskie do form retoryki i epistolografii pogańskiej, ale „specyfika treści w zasadzie nie wymuszała użycia nowych środków z zakresu języka, nie powoduje, że zasady konstrukcji tekstów znane dotychczas z traktatów starożytnych przestają być aktualne"41. Na podstawie nawet tak niewielkiego tekstu jak Flm widać kunszt retoryczny Pawła i nie ma podstaw ani nawet przesłanek, aby retorykę Pawłową, czy późniejszą, chrześcijańską, oddzielać pod względem formalnym od cieszącej się w starożytności ogromnym powodzeniem retoryki antycznej.

Nasuwa się jeszcze jeden wniosek, może nieco poboczny w stosunku do powyższych rozważań - skoro Flm jest wzorcowym przykładem listu polecającego, należy go traktować w taki właśnie sposób - jako list wstawienniczy skierowany do osoby prywatnej - mimo że przeznaczony był również do publicznego odczytania, jak na to wskazuje wiersz 2. Nie trzeba jednak dopatrywać się w nim jakiegoś szerszego socjologicznego apostolskiego manifestu na temat niewolnictwa ${ }^{42}$. Celem, jaki Paweł chce osiągnąć, nie jest więc przekonanie kogokolwiek do zniesienia niewolnictwa (nawet nie wiadomo dokładnie, czy Paweł żąda uwolnienia polecanego Onezyma) ${ }^{43}$, ale skłonienie Filemona do przyjęcia zbiegłego sługi już nie jako niewolnika, lecz jako równorzędnego partnera.

Warszawa

KALINA WOJCIECHOWSKA

${ }^{39}$ R. Andrzejewski, art. cyt., s. 23.
${ }^{40}$ Tamże.
${ }^{41}$ M. TKacz, art. cyt.
${ }^{42}$ P. Stuhlmacher, dz. cyt., s. 57.
${ }^{43}$ S. MęDala, Pawet i niewolnictwo. (List do Filemona), w: Dzieje Apostolskie. Listy św. Pawła (Wprowadzenie w myśl i wezwanie ksiąg biblijnych, red. J. Frankowski, t. 9), Warszawa 1997, s. 413. 